\title{
Influence of Livestock Farming on Vegetation in a Degraded Soil Area on the East Coast of Lake Victoria in Western Kenya: A Case Study of Jimo East Sub-Location in Nyando Sub-County
}

\author{
Yuko Yamane1 ${ }^{*}$, Shuichi Asanuma1, Kazuhiro Umenura² \\ ${ }^{1}$ International Cooperation Center for Agricultural Education (ICCAE), Nagoya University, \\ Nagoya, Japan \\ ${ }^{2}$ NARO Hokkaido Agricultural Research Center, Sapporo, Japan \\ Email: "yamane@agr.nagoya-u.ac.jp
}

Received 1 July 2015; accepted 11 August 2015; published 14 August 2015

Copyright (C) 2015 by authors and Scientific Research Publishing Inc.

This work is licensed under the Creative Commons Attribution International License (CC BY). http://creativecommons.org/licenses/by/4.0/

\section{(c) (i) Open Access}

\begin{abstract}
In the study area located in Western Kenya near the Lake Victoria, severe soil erosion occurred and it thought to relate to vegetation degradation caused by overgrazing. The livestock density estimated by analyzing satellite image (1.39 TLU/ha for available grazing lands) was lower than that of measured for seven farmers' grazing lands using GPSs (4.41 TLU/ha, 2011) with variation from 0.83 to $12.36 \mathrm{TLU} / \mathrm{ha}$. Thus, it is clear that the grasslands used by farmers are limited compared with the area of estimated available land for grazing identified by analyzing the satellite image. According to growth-consumption rate model that was developed by the Nyangito et al. (2008) in southeastern Kenya, if livestock density reaches over $7 \mathrm{TLU} / \mathrm{ha}$, pasture growth rate became lower than consumption rate. Grass biomasses of the grazing lands were kept low (less than $50 \mathrm{~g} / 50 \times$ $50 \mathrm{~cm}^{2}$ ) under high livestock density (three farmers out of seven were higher than $7 \mathrm{TLU} / \mathrm{ha}$ ). In addition, rainfall pattern is very unstable and we observed stunted growth of grasses during dry spells. Therefore, we concluded that overgrazing. It means that inhibition of continuous re-growth of grasses due to high grazing pressure has been occurred even for small area and contributed to the soil erosion.
\end{abstract}

\section{Keywords}

Luo, Overgrazing, Soil Erosion, TLU, Western Kenya

\footnotetext{
${ }^{*}$ Corresponding author.

How to cite this paper: Yamane, Y., Asanuma, S. and Umenura, K. (2015) Influence of Livestock Farming on Vegetation in a Degraded Soil Area on the East Coast of Lake Victoria in Western Kenya: A Case Study of Jimo East Sub-Location in Nyando Sub-County. Journal of Environmental Protection, 6, 824-836. http://dx.doi.org/10.4236/jep.2015.68075
} 


\section{Introduction}

It is well known that topsoil is being depleted through various human activities. While topsoil develops over centuries, the world's growing human population is actively depleting this resource over decades [1]. Across Africa, overgrazing and agricultural activities are a major cause of land degradation [2] [3]. Many farmers living in rural areas in Africa have traditionally obtained their food through agriculture. Therefore, loss of the topsoil means that these farmers are in danger of losing their livelihood.

Western Kenya has one of the highest rural population densities in Africa, and soil erosion occurs both often and severely [1]. In particular, the Nyando River basin located on the east coast of Lake Victoria has been identified as a hot spot region of erosion [4]-[6]. The people living in this basin are mostly Luo, who are presently engaged in livestock farming, and have been pastoralists for a long time. Ong'or (2005) suggested that livestock farming might influence the expansion of soil erosion in this basin [7]. Therefore, countermeasures such as controlling the population of livestock in Nyando River basin are required in order to reduce the rate of soil erosion.

In our study area, information about population and density of livestock is very limited and descriptive [8], meaning that it is difficult to estimate the impact of livestock farming on the soil erosion in this area. Shinjo (2003) reported that overgrazing inhibited continuous re-growth of grasses due to high grazing pressure [9]. In this study, using the hypothesis of overgrazing, the influence of livestock farming is discussed as a cause of soil erosion through the degradation of vegetation, based on livestock density per hectare (ha), size of the grazing area, and the biomass of grasses.

\section{Study Area}

The Nyando River runs from the highlands of Nyando Province about $2000 \mathrm{~m}$ above sea level (asl) to Lake Victoria at $1184 \mathrm{~m}$ asl. Four hundred and fifty to 500 years ago or earlier, the Luo, Nilotic people who emigrated from Sudan to the northern coastline of Lake Victoria, included the Nyando River basin [10]. In the society of Nilotic-speaking people including the Luo, cattle have crucial cultural and economic roles [11]. Up to the present day, the Luo in the Nyando River basin have engaged in pastoral, farming- or a fishing-based way of life. The study area $\left(0.18^{\circ} \mathrm{S}-0.19^{\circ} \mathrm{S}, 34.59^{\circ} \mathrm{E}-35.23^{\circ} \mathrm{E}\right)$, the Jimo East sub-location in Nyando sub-county, is elevated 1100 - $1300 \mathrm{~m}$ asl. In this sub-location, several gullies have been formed and the longest one stretches over $10 \mathrm{~km}$, with the deepest gully exceeding $20 \mathrm{~m}$ in depth. Mixed farming of cereal cultivation and livestock farming are common in this region. This sub-location faces the border of the Rift Valley Province, in which most people are Kipsigis, and are engaged in intensive farming, including tea cultivation [12]. The Kipsigis lands near the border are extensively used, and some lands are rented to the Luo people for use in grazing and farming.

Average annual rainfall around Lake Victoria exceeds $1000 \mathrm{~mm} /$ year. In fact, according to the rainfall data at the Kibos Center of Kenya Agricultural Research Institute (KARI), located about 50 km northeast of the study area, the average annual rainfall for 57 years, from 1952 to 2008, was $1306 \mathrm{~mm} /$ year, the long rains peaking between April and May and the short rains between November and December.

Daily precipitation in the study area was measured by rain gauge (3639 pulse, Hioki Electric LTD., Japan) from April 2, 2009 to March 18, 2010, and is shown in Figure 1. Total rainfall was 1546.5 mm. It rained frequently from April to May, but thereafter until November, the daily precipitation was less than $20 \mathrm{~mm}$. The study area is close to the equator where solar energy is very high [13]. If it does not rain for more than one month, grasses may become very dry, causing cattle to starve to death. In fact, we observed that most grasses had dried up and some cattle had died in March 2009 and February 2011 although no rainfall data for these months was available. Our data (Figure 1) shows that it did not rain for 26 days, from January 10 to February 4 but immediately after then, it rained heavily on February 5, 6, and 8, 2010 at 112, 86, and 76 mm/day, respectively. Although, the number of days with over $20 \mathrm{~mm}$ precipitation was only 19 days out of 355 (5.4\%), the amount of rainfall on these days was $889.5 \mathrm{~mm}$ (57.5\%). Thus, more than half of the annual rainfall fell in a just a few days with high rainfall intensity between December and May.

\section{Methods}

The author Yamane stayed with a host family in the study area for a total of seven months, from March to May 2009, January to March 2010, and February 2011. The daily life of the people and their agricultural ways, were 


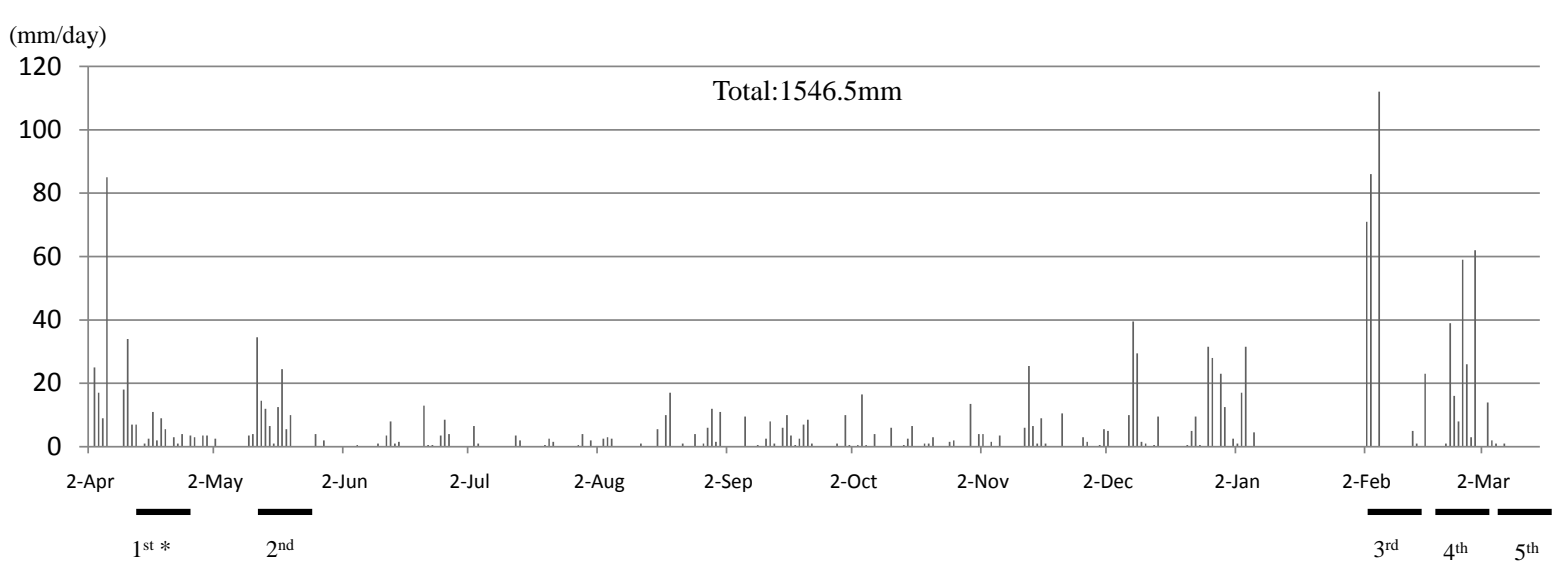

Figure 1. Daily precipitation in study area from April $2^{\text {nd }} 2009$ to March $18^{\text {th }} 2010 . .^{*}:$ Each bar shows the period of surveying grazing locations and its area sizes.

determined using the participatory observation method, and the following investigations were conducted.

\subsection{Evaluation of Livestock Density Using Satellite Imaging}

An RGB image of the study area was created from Digital Globe's orthorectifed Quickbird image taken on April 14, 2009 using GIS software, GRASS6.4.0. Most of the study area was located in the Luo land in the Jimo East sub-location, but extended partly in to the Kipsigis lands, which were rented by the Luo people (Figure 2). On the image, the land was divided into smaller pieces surrounded by boundaries; each piece of this land is called a "compartment" in this report. The compartments were observed in both the Luo and Kipsigis lands. During the ground observation, it was found that perennial crops such as the Euphorbia family or sisal were generally planted on boundaries. According to the result of a seven month-participatory observation, it was found that there were three categories of compartment use: household, cultivated, and grassland compartments. The grassland compartments were used for grazing livestock and the compartments with houses were considered as household compartments. On the other hand, where there were no houses in the compartments, they were considered as cultivated or grassland compartments. Plowing or tilling of the lands occurred from late March to April, following by seeding of staple food crops such as maize or sorghum. In a satellite image from April 17, 2009, the cultivated compartments appeared as dark brown, because crops sown after plowing were still small at this time. On the other hand, the grassland compartments looked green due to the grass. Therefore, grassland compartments could easily be differentiated from cultivated compartments. Thus, it was possible to classify all compartments into grassland (653 compartments), cultivated (820), or household compartments (541) (Table 1). All households of the Luo people were located only on the Luo land. Forty-five households out of a total 541 were interviewed using questionnaires in May 2009 seeking a livestock head-count per household. Interviewed households were randomly selected from all over the study area.

Levels of vegetation in each cultivated, grassland, and household compartments were classified as level 0,1 , 2, 3, or 4 following the criteria shown in Table 2. The total land area of each vegetation level was calculated to estimate the possible grassland area for grazing. Household compartments could also be used both for grazing and crop cultivation. However, crops had yet to grow large when the satellite image was taken; therefore, the green spaces within household compartments were estimated as grasslands for grazing. A space occupied by houses was classified as a non-grazing area.

\subsection{Land Size and Livestock Density of Compartments Used for Grazing}

The location and size of compartments used for grazing were surveyed six times within three years; twice in April and May 2009, three times in February and March 2010, and once in February 2011. This was performed using GPS (SONY PCQ-HGR3S in 2009, Germin e-Trex Venture HC in 2010 and 2011, respectively) and a byte counter [14], to clarify differences between the season and year.

Farmers keeping a large number of cattle need more grasslands for grazing, compared with those keeping a 

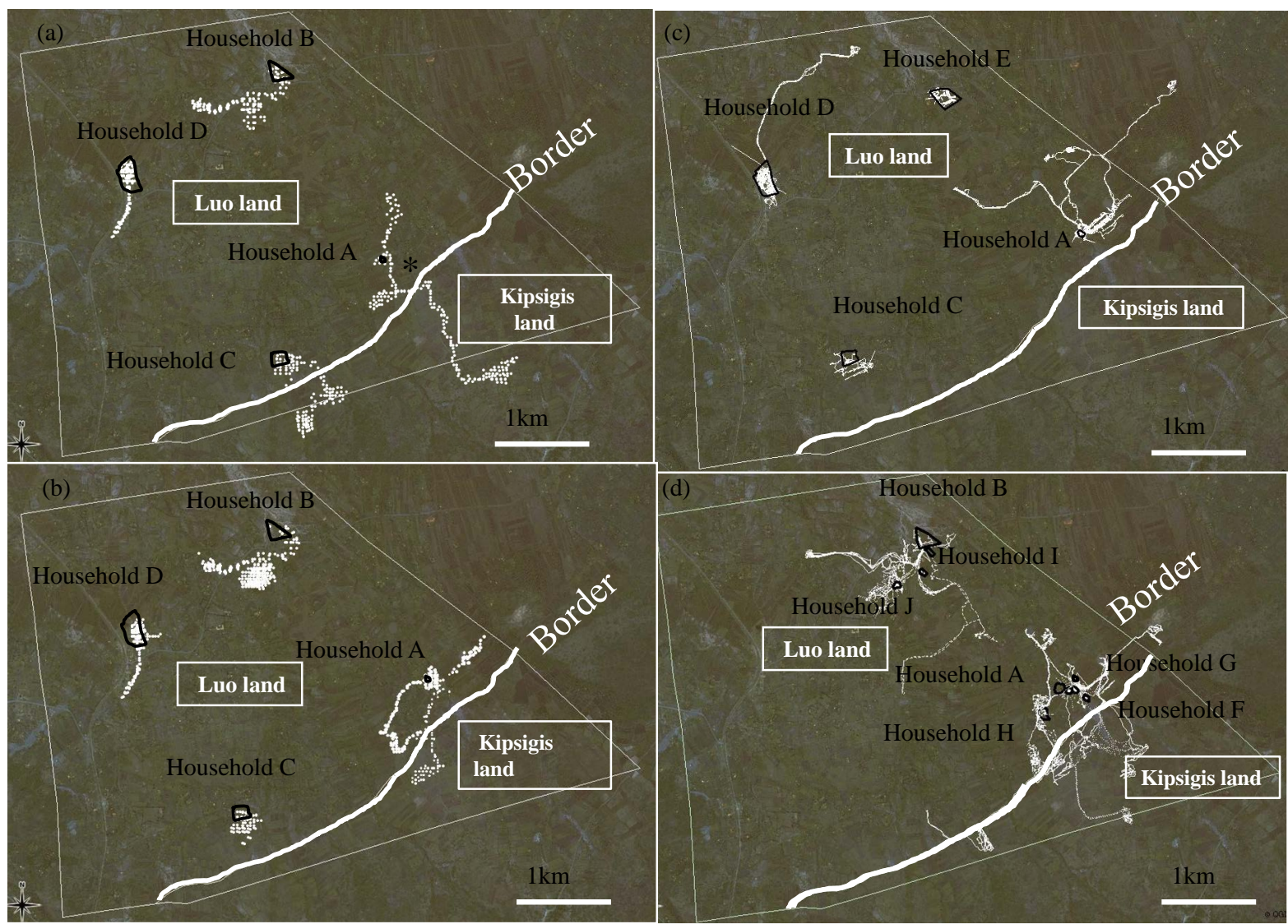

Figure 2. Locations of farmers' household and grassland compartments and the trace of their cattle and sheep moving toward grazing surveyed (a) in April; (b) in May 2009; (c) in February and March 2010 and (d) in February 2011. *:Household A farmer took his cattle to a grassland compartment in the Kipsigis land located about $2.5 \mathrm{~km}$ far from his compartment in the Luo land. His diurnal grazing pattern was observed also in May when grass grew well.

Table 1. Number of compartments and its land sizes of different land uses and vegetative conditions.

\begin{tabular}{|c|c|c|c|c|c|c|c|c|}
\hline \multirow{3}{*}{$\begin{array}{c}\text { Vegetation } \\
\text { level }^{*}\end{array}$} & \multicolumn{2}{|c|}{ Household compartment } & \multicolumn{2}{|c|}{ Cultivated compartment } & \multicolumn{2}{|c|}{ Grassland compartment } & \multicolumn{2}{|c|}{ Total } \\
\hline & Compartment & $\begin{array}{l}\text { Average } \\
\text { land size }\end{array}$ & Compartment & $\begin{array}{l}\text { Average } \\
\text { land size }\end{array}$ & Compartment & $\begin{array}{l}\text { Average } \\
\text { land size }\end{array}$ & Compartment & Average land size \\
\hline & (Number) & (ha) & (Number) & (ha) & (Number) & (ha) & (Number) & (ha) \\
\hline Level 0 & $-^{* *}$ & - & 355 & $0.27 \pm 0.20$ & - & - & 355 & $0.27 \pm-$ \\
\hline Level 1 & $25^{* * *}$ & $2.5 \pm 0.37^{* * *}$ & 465 & $0.33 \pm 0.26$ & - & - & 490 & $0.44 \pm-$ \\
\hline Level 2 & 342 & $0.39 \pm 0.15^{* * * *}$ & - & - & 534 & $0.61 \pm 0.58$ & 876 & $0.52 \pm 0.49$ \\
\hline Level 3 & 164 & $0.39 \pm 0.16$ & - & - & 108 & $0.81 \pm 0.63$ & 272 & $0.56 \pm 0.51$ \\
\hline Level 4 & 10 & $0.27 \pm 0.12$ & - & - & 11 & $0.36 \pm 0.22$ & 21 & $0.32 \pm 0.19$ \\
\hline Total & 541 & 0.48 & 820 & 0.30 & 653 & 0.64 & 2014 & 0.46 \\
\hline
\end{tabular}

${ }^{*}$ : Criteria of the classification of each vegetation level was shown in Table 2. ${ }^{* *}$ : represent no data or data could not calculate. ${ }^{* * *}$ : Vegetative analysis of household compartment did not classify level 0 and 1 . Figures show total number of level $0+$ level $1 .{ }^{* * * *}$ : The figure is shown as mean \pm standard deviation.

small number. In a preliminary participatory observation, two grazing patterns, a) grazing only inside the household compartment, and b) grazing both inside and outside were detected. The difference in these grazing patterns depended on the number of cattle. Farmers keeping only one or two cattle tended to follow pattern a), 
Table 2. Criteria for classification of compartments*.

\begin{tabular}{ccc}
\hline Criteria & Green vegetation & Tree \\
\hline Level 0 & None & (None or a few) \\
Level 1 & Less than half land area & (None or a few) \\
Level 2 & More than half land area & (None or a few) \\
Level 3 & More than half land area & Less than half land area \\
Level 4 & More than half land area & More than half land area ${ }^{* *}$ \\
\hline
\end{tabular}

*: A compartment was classified based on the land area of green vegetation and the land area of the presence of trees. ${ }^{* *}$ : Commonly, trees were observed within land area that grass was grown.

whereas those keeping more cattle tended to follow pattern b). Thus, farmers following pattern b) might have a bigger impact on reducing land vegetation than those adopting pattern a). Therefore, in this survey, these two types of farmers were chosen.

The survey was carried out over five successive days, by attaching GPS and bite counters to the necks of cattle. Four farmers keeping more than five cattle (Households A, B, C, and D) and three farmers (Households A, C and D) were selected in 2009 and 2010, respectively (Figures 2(a)-(c)). One farmer (Household E) keeping only two cattle was employed for comparison in 2010. In February 2011, five more farmers keeping a large number of cattle (Households G, H, I, J, and K) were employed and their sheep were used in the survey.

\subsection{Biomass of Grasses}

While surveying livestock behavior, the biomass of grasses from four compartments (Households A, B, C, and D in 2009, Households A, C, D and E in 2010) was measured. Three grass samples were taken at random from each household compartment for each measurement. Seven measurements were made for Household B at weekly intervals for two months, from April to early June, in 2009. Four measurements were made in the same period in Households A, C, and D. In 2010, three measurements were made in the two months, from February to March. All grasses within a square area of $50 \times 50 \mathrm{~cm}^{2}$ were cut at ground level for dry weight analysis. All harvested grasses were dried in paper bags in the oven at $70^{\circ} \mathrm{C}$ for three days before weighing. In 2011, the biomass from 10 compartments was measured on August 5 and 6. This included seven grassland and three household compartments, distributed throughout the study area to determine the variation in biomass among different locations.

A rain gauge (3639-20 Pulse Logger, Hioki E. E. Corporation, Japan) was set up on April 2, 2009 to measure daily rainfall in the inner grass garden of Dori-Secondary School located within the study area.

\section{Results and Discussion}

\subsection{Evaluation of Livestock Density Using Satellite Images}

In the study area, many farmers raised domestic animals such as cattle, goats, and sheep on grazing land. Dairy cattle and dairy goats are reared for milk and other small ruminants, goats and sheep, are reared for meat. Households were classified into five types based on the livestock farming composition of animals: Group A (cow + bull + small ruminants), B (cow + small ruminants), C (cow or bull), D (small ruminants), and E (no animals) (Table 3). The proportions of Groups A, B, C, D, and E among 45 households were $15.6 \%$, 28.9\%, $11.1 \%, 28.9 \%$ and $15.6 \%$, respectively.

The 541 households were classified in Table 1 and their livestock animals were estimated by extrapolation of the data based on the proportions observed with 45 households. The results are shown in Table 3 . The households of Group A to E were 84, 156, 60, 156, or 84 and cows, bulls or small ruminants were 727.3 , 296.5, or 1449.9, respectively.

The compartments were categorized based on their vegetation levels (Table 2) and their land sizes were estimated from the satellite image (Table 1). Among a total of 2014 compartments, household compartments, cultivated compartments, or grassland compartments numbered 541 with an average area of 0.48 ha, 820 with 0.30 ha, and 653 with 0.64 ha. The average size of compartments was 0.46 ha. Household compartments (541) were 
Table 3. Groups of livestock farming and its head-count of different livestock.

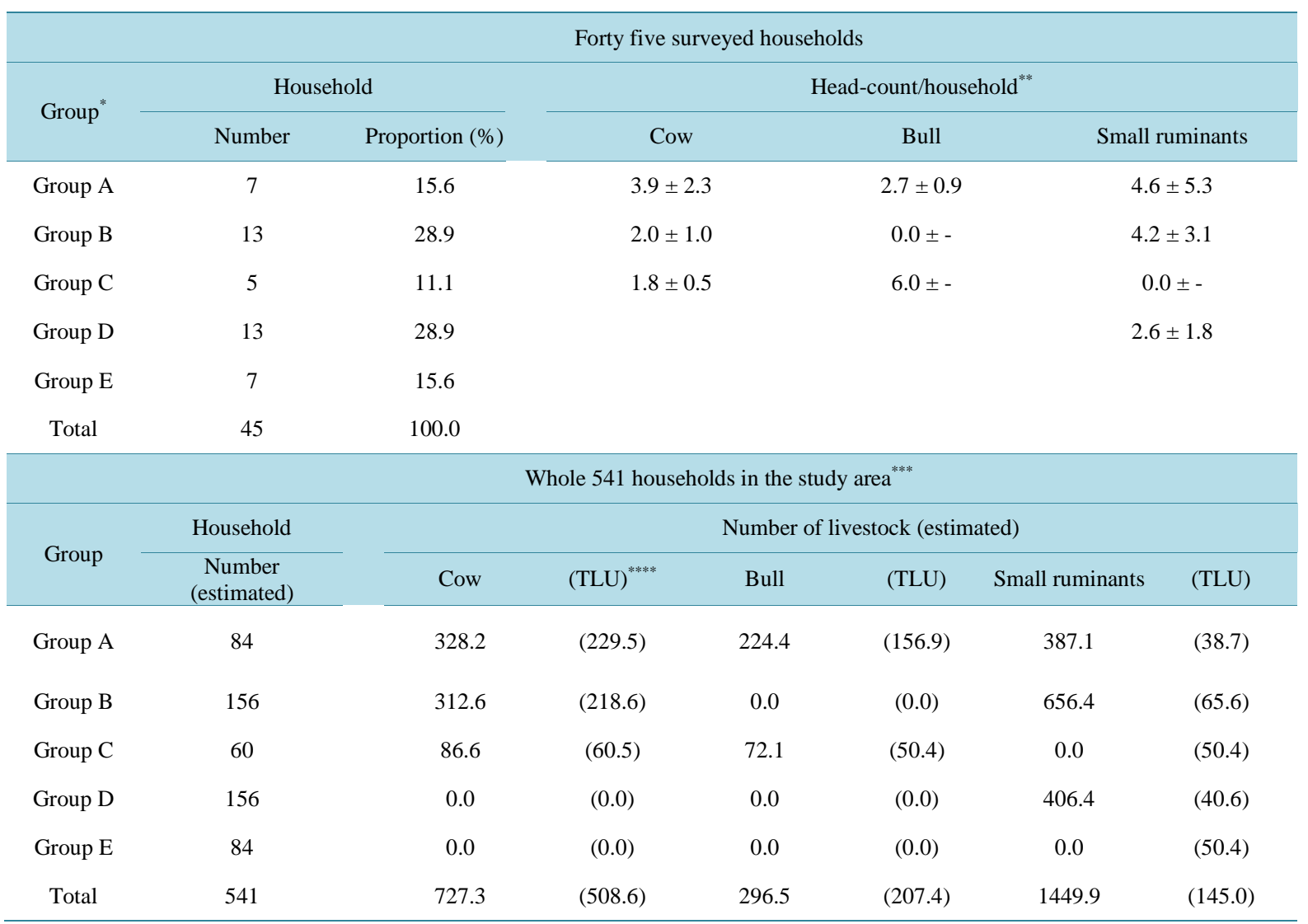

*: Households were classified into 5 Groups based on the Group of keeping livestock: Group A (cow + bull + small ruminant), Group B (cow + small ruminant), Group C (cow or bull), Group D (small ruminants), Group E (no livestock). ${ }^{* *}$ : The figure is shown as mean \pm standard deviation. ${ }^{* * *}$ : The figures of households or livestock calculated number based on the proportion of households or the mean value of livestock shown in the results of 45 surveyed households, respectively. ${ }^{* * * *}$ : TLU: Tropical livestock units, one TLU equal to $250 \mathrm{~kg}$ live weight and it reported as 1.43 cattle (cow or bull) or 10 small ruminants (D. Bourn and W. Wint, 1994).

classified based on their vegetation levels into level 1 (25, 4.6\%), level 2 (342, 63.2\%), level 3 (164, 30.3\%), and level 4 (10, 1.8\%) (Table 1). Grassland compartments were similarly classified into level 2 (534, 81.8\%), level 3 (108, 16.5\%), and level 4 (11, 1.6\%) (Table 1). As shown in Table 2, herbaceous vegetation covered more than half of the land areas in levels 2, 3, and 4 that could be used for grazing. On the contrary, little vegetation was observed in levels 0 and 1 , which may not be available for grazing. Accordingly, the compartments of vegetation levels 2, 3, and 4 were considered to be available for grazing and its total land area (levels $2+3+4$ ) was estimated as 617.9 ha (66.6\% of total land area) composed of 1169 (58.0\%) compartments.

Head-count of cattle (cow and bull) or of small ruminants can be converted into tropical livestock units (TLU) for ease of comparison [15]. One unit of TLU represents $250 \mathrm{~kg}$ live weight, equivalent to one camel, 1.43 cattle, or 10 small ruminants. In this study, TLU for cattle (cow + bull), or for all livestock against available grazing lands (levels $2+3+4$ ) was 1.16 TLU/ha (716.0 TLU/617.9 ha) or 1.39 TLU/ha (861 TLU/617.9 ha), respectively (Table 3).

Wint and Bourn (1994) reported that TLU is strongly correlated with mean annual rainfall in sub-Saharan Africa [16]. TLUs in the region of $500 \mathrm{~mm}$ annual rainfall, in sub-humid zone of less than $1000 \mathrm{~mm}$, and in the humid zone were $0.183,0.148$, and $0.09 \mathrm{TLU} / \mathrm{ha}$, respectively. Peak TLU, at $0.21 \mathrm{TLU} / \mathrm{ha}$, was achieved at around $825 \mathrm{~mm}$ annual rainfall, and declined to zero at about $2500 \mathrm{~mm}$. Pastoral livestock seems to be absent from the very wet area, presumably because of the threat of vector-borne and other diseases. In our study area, the rainfall reached over 1500 mm between April 2009 and March 2010, but livestock could survive because the area is not wet throughout the entire year and long dry spells are observed frequently (Figure 1). The livestock density in the study area, $1.16 \mathrm{TLU} / \mathrm{ha}$ for cattle or $1.39 \mathrm{TLU} / \mathrm{ha}$ for whole livestock, was approximately six 
times higher than the maximum level, 0.21 TLU/ha, in sub-Sahara [15]. In Zimbabwe, cattle density fluctuated between 20 - $60 \mathrm{head} / \mathrm{km}^{2}(0.14$ - $0.41 \mathrm{TLU} / \mathrm{ha})$ over the 26 years, from 1960 to 1986, in communal areas with low management and annual rainfall of 760 - $1054 \mathrm{~mm}$ mainly due to the fluctuation of rainfall and prevalence of disease [17]. The maximum level in Zimbabwe (0.41 TLU/ha) was approximately one third of that observed in this study (1.39 TLU/ha). Thus, the livestock density in our study area is considerably higher than that of other areas in sub-Saharan Africa. Consequently, grazing pressure on the land is greater in our study region.

\subsection{Biomass of Grasses}

Variations were observed in the dry weight of grasses among different household compartments, harvesting times, and between years (Figure 3). In general, higher dry weights were obtained in the same household compartments in February to March 2010 (from January 18 to March 18, $530 \mathrm{~mm}$ ) than in April to May 2009 (from April 2 to June 2, $391 \mathrm{~mm}$ ), probably due to the higher rainfall during the former period (Figure 1).

In fact, it was extremely dry in March 2009 (data not shown), and conditions were unfavorable for the growth of grasses, resulting in mean dry weights of less than $10 \mathrm{~g}$ per unit area $\left(50 \times 50 \mathrm{~cm}^{2}\right)$ (Figure 3(a)). In May 2009, grasses grew better than in April but were still retarded due to the limited rainfall, compared with the growth observed in February and March 2010 (Figure 3(b)). Thus, the higher rainfall measured in 2010 might have promoted increased growth of grasses even in the same household compartments. In 2011, no significant difference was observed in the dry weights of grasses among grassland and household compartments, although larger variations were observed in the same harvested compartments (Figure 4). Small weights in sites three and four might be due to poor soil conditions, different types of grasses, and/or the history of grazing.

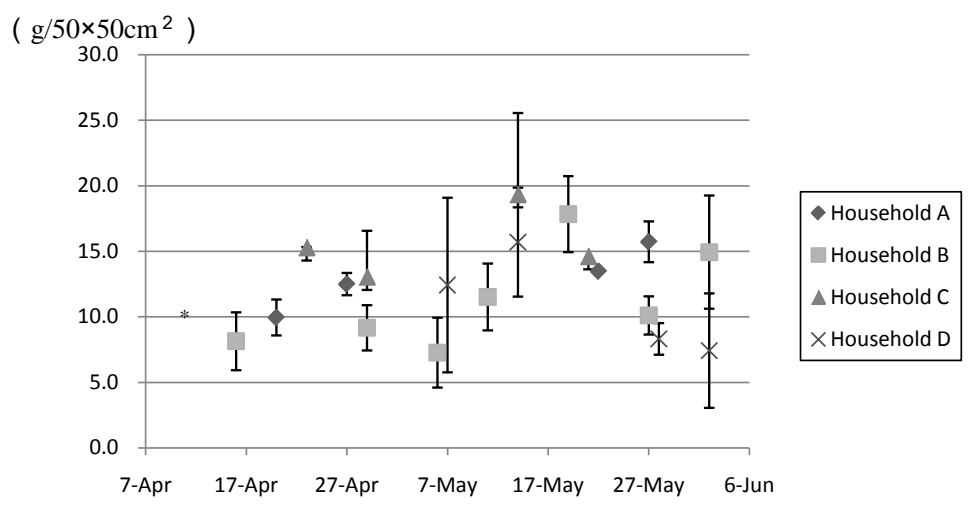

(a)

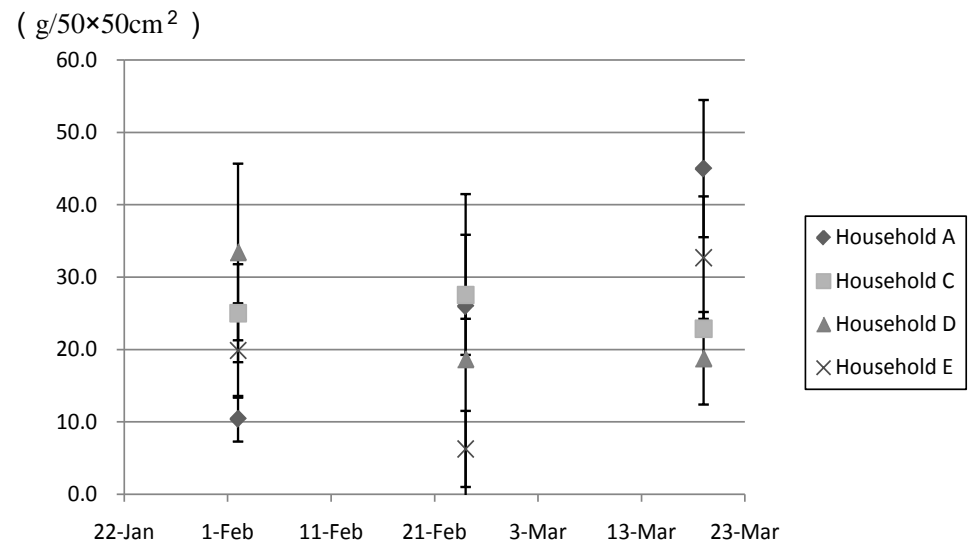

(b)

Figure 3. Dry weight of grasses taken in household compartments in Aprilearly-June 2009(a) and February-March 2010(b). *: Vertical bar of each symbol represents standard deviation of three samples. 


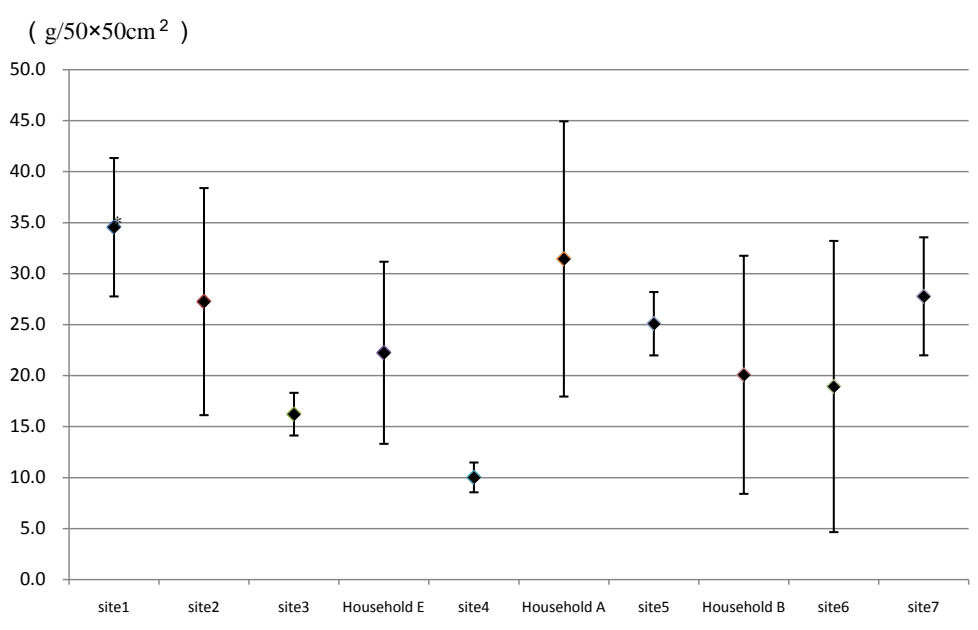

Figure 4. Dry weight of grasses of $50 \times 50 \mathrm{~cm}^{2}$ in 7 grassland and 3 household compartments in August 2011. *: Data were shown as an average of dry weight grass with standard deviation of three replications.

Even though low grass weights were observed in some areas, the dry weight of grasses varied from 2.5 to $23.7 \mathrm{~g}$ (12.3 g average) in 2009, 3.6 to $53.9 \mathrm{~g}$ (23.9 g average) in 2010, and 6.7 to $46.3 \mathrm{~g}$ (22.9 g average) in 2011, respectively (Figure 3 and Figure 4). Thus, within the 3 years in the study area, the grass biomass fluctuated largely, probably due to environmental reasons such as rainfall. However, levels did not reach the $50.0 \mathrm{~g} /$ $50 \times 50 \mathrm{~cm}^{2}(2000 \mathrm{~kg} / \mathrm{ha})$ levels throughout the three years. In fact, the overall average of three years was $19.1 \mathrm{~g} /$ $50 \times 50 \mathrm{~cm}^{2}$ (763.8 kg/ha). The average biomass of our study area was $763.8 \mathrm{~kg} / \mathrm{ha}$ and even the maximum value was $2154.8 \mathrm{~kg} / \mathrm{ha}\left(53.9 \mathrm{~g} / 50 \times 50 \mathrm{~cm}^{2}\right)$ observed in 2010. Gufu et al (2001) reported that the biomass of grasses in the arid-zone in northern Kenya, with an annual rainfall of $500 \mathrm{~mm}$ [18], is $1800 \mathrm{~kg} / \mathrm{ha}$, which is about 2.5 times higher than the average biomass of $763.8 \mathrm{~kg} / \mathrm{ha}$ in our study area, in spite of 1/3 annual rainfall. Therefore, the biomass production of grasses in our study area was found to be very small. It is possible that the low weight of biomass in this area might be caused by a vulnerable rainfall pattern and continued grazing.

\subsection{Land Size and Livestock Density in the Grassland Compartments}

\subsubsection{Bite Counter}

Farmers kept their animals in cattle pens ("kul" in Luo language) at night, located in the center of their household compartments. Cattle were released from kul early in the morning, and started grazing around the house. Before, or around noon, farmers took cattle to the grassland compartment where they remained until evening. Bite counter showed that grazing started between 8:00 and 9:00 am whilst in their household compartments (Figure 5), Around noon, biting declined sharply (Figure 5(a) and Figure 5(b)), coinciding with the move to grazing. In 2009, rainfall began on March 31, at the start of the rainy season, meaning that grasses grew poorly in the Luo land in the study area in early April. Accordingly, farmers from households A and C took their cattle up to the hillside in the Kipsigis land to seek grasses (Figure 2(a) and Figure 2(b)). Cattle bites reached an average of 62,997 bites/day over five successive days in April 2009, and reduced drastically to 14,572 bites/day in May of the same year (Figure 2(b) and Figure 5(a)). As shown in Figure 3, the biomass of grasses in the Luo land was greater in May than in April, and probably resulted in the observed reduction of cattle bites.

\subsubsection{Moving for Grasses}

The movements of cattle for grazing in April and May 2009, February and March 2010, and February 2011 were traced by GPS (Figure 2). Two farmers (Households A and C) out of four changed grazing lands between April 2009 and May 2009 (Figure 2(a) and Figure 2(b), Table 4). The farmer from Household A went into the Kipsigis land, whereas Household C stayed within the Luo land. Conversely, farmers from Households B and D used the same grassland compartments, which were located near their household compartments (Figure 2(a) and Figure 2(b)).

In 2010, the farmer from Household A used three different grassland compartments from those used in 2009, 

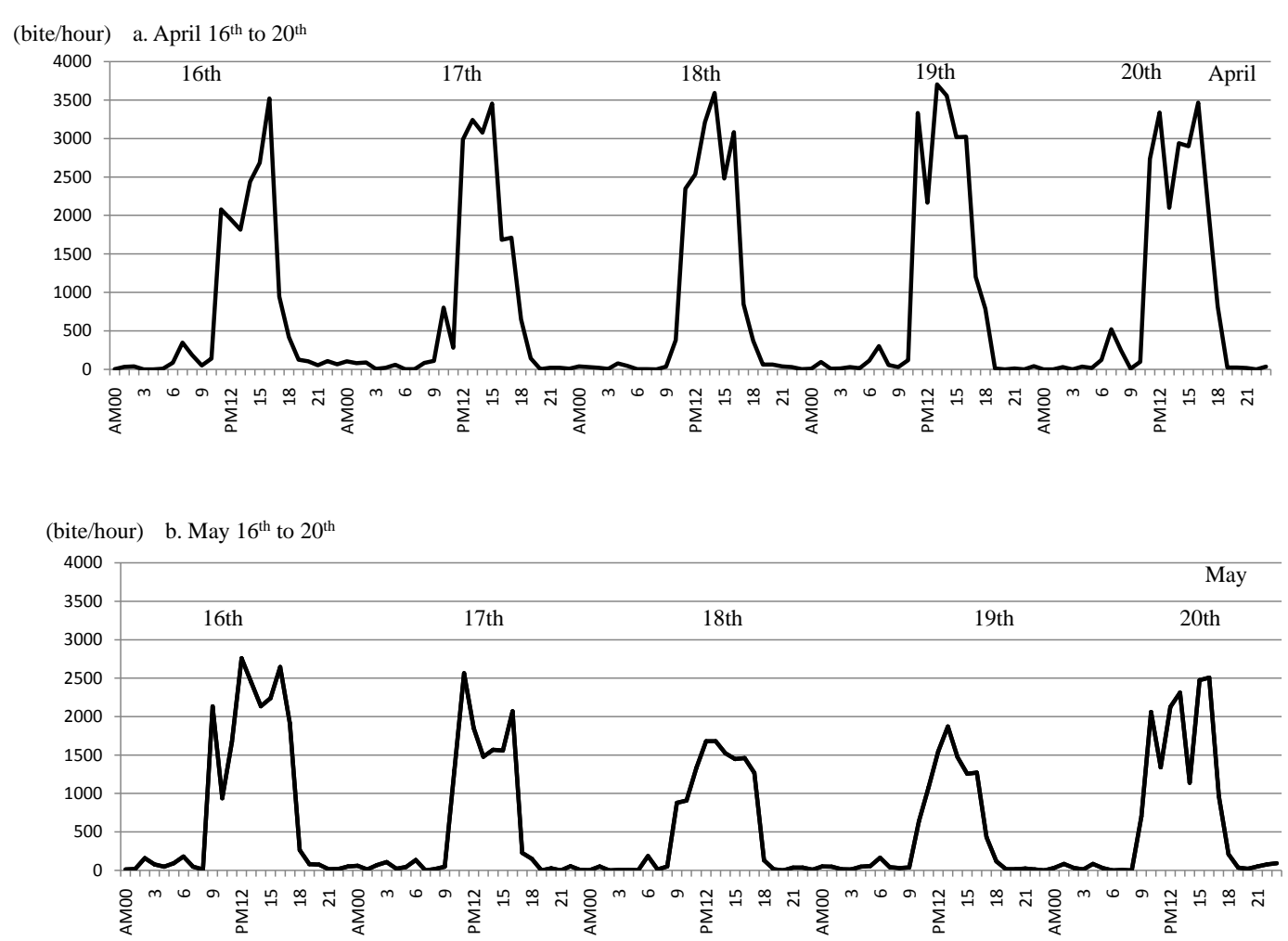

Figure 5. Grazing pattern of cattle of Household A for 5 successive days in different month in 2009 measured by a bite counter attached to cattle neck.

Table 4. Number and total size of household and grassland compartments used by 10 households for grazing and their livestock number.

\begin{tabular}{|c|c|c|c|c|c|c|c|c|c|c|c|c|}
\hline & & & & & & & & & & \multicolumn{3}{|c|}{ Livestock number } \\
\hline & \multicolumn{3}{|c|}{$\begin{array}{c}\text { Number of } \\
\text { compartments }\end{array}$} & \multicolumn{3}{|c|}{ Total land size (ha) } & \multicolumn{3}{|c|}{ cattle } & \multicolumn{3}{|c|}{ small ruminants } \\
\hline & 2009 & 2010 & 2011 & 2009 & 2010 & 2011 & 2010 & 2011 & 2009 & 2010 & 2011 & 2011 \\
\hline Farmers ${ }^{*}$ & Apr & May & Feb, Mar & Feb & Apr & May & Feb, Mar & Feb & Apr, May & Feb, Mar & Feb & Feb \\
\hline Household A & 4 & 4 & 4 & 4 & 9.3 & 4.2 & 1.7 & 6.2 & 11 & 10 & 11 & 11 \\
\hline Household B & 3 & 3 & - & 3 & 5.6 & 5.6 & - & 1.2 & 11 & - & 11 & 44 \\
\hline Household C & 3 & 1 & 1 & - & 13.7 & 5.0 & 4.8 & - & 12 & 10 & - & - \\
\hline Household D & 1 & 1 & 2 & - & 2.2 & 2.2 & 2.3 & - & 11 & 7 & - & - \\
\hline Household E & $-^{* *}$ & - & 1 & - & - & - & 0.1 & - & - & 2 & - & - \\
\hline Household F & - & - & - & 2 & - & - & - & 1.7 & - & - & 10 & 4 \\
\hline Household G & - & - & - & 3 & - & - & - & 1.2 & - & - & 7 & 9 \\
\hline Household H & - & - & - & 3 & - & - & - & 4.4 & - & - & 17 & 32 \\
\hline Household I & - & - & - & 1 & - & - & - & 4.4 & - & - & 5 & 10 \\
\hline Household J & - & - & - & 1 & - & - & - & 0.4 & - & - & 6 & 6 \\
\hline
\end{tabular}

${ }^{*}$ : See Figure 2. ${ }^{* *}$ : no data.

and changed compartments every day (Figure 2(c)). On the contrary, farmers from Households C and D used the same compartments as in 2009. Moreover, Household D used additional grassland compartment near to the Household E compartment (Figure 2(c)). In the case of the farmer from Household E who kept only two cows, 
and employed grazing pattern a), his cows were tethered inside his household compartment and the tethered position was adjusted several times each day.

Seven farmers were surveyed in 2011, three in the northern part and four in the southern part of the study area (Figure 2(d)). The farmer from Household A used four grassland compartments, as he did in 2009 and 2010 (Figures 2(a)-(d)). His neighbors, farmers from Households G, H, and F also used four grassland compartments that were located a short distance from their household compartments, some in the Kipsigis land, although they were all located near each other (Figure 2(d)). Conversely, farmers from Households I and J used grassland compartments near their households. The farmer from Household I took his cattle a short distance from his household compartment for grazing. The Household B farmer used two more grassland compartments in addition to his household compartment, one of which was the same used in 2009, whilst the other one was new; both compartments were located near his household compartment (Figure 2(a), Figure 2(b) and Figure 2(d)). In general, small ruminants were taken to the same grassland compartments as cattle.

\subsubsection{Land Size}

Land size of grazing lands, livestock numbers, livestock density and grass density of 10 households are shown in Table 4 and Table 5. Land size used for grazing by each household, grassland compartments, and household compartment, were measured and traced by GPS on the satellite image (Figures 2(a)-(d)). Land size used by Household A for grazing in 2010 was half the size of that used in 2009, whereas livestock density was more than doubled (Table 4 and Table 5). The farmer from Household A changed the size and location of grasslands for grazing in different seasons in 2009. In 2010, he used a smaller area than in May 2009. It is likely that this was because of the better condition of the grass biomass in 2010 compared to May 2009 (Figure 3(a) and Figure 3(b)). On the other hand, farmer from Households B and D remained around and/or near their household compartments in both April and May despite less growth of grasses in April than in May 2009 (Figure 2(a) and Figure 2(b), Figure 3).

In the case of Household C, land sizes used for grazing in May drastically reduced from April in 2009, whilst the livestock density increased (0.61 TLU/ha in April to $1.66 \mathrm{TLU} / \mathrm{ha}$ in May) (Table 5). The land size of

Table 5. Livestock density and the available grasses for animals*.

\begin{tabular}{|c|c|c|c|c|c|c|c|c|c|c|c|c|}
\hline & \multicolumn{5}{|c|}{ Livestock density (TLU/ha) } & \multicolumn{7}{|c|}{ Available grasses for animals (kg/TLU) ${ }^{* *}$} \\
\hline & \multirow{3}{*}{$\begin{array}{l}2009 \\
\text { cattle } \\
\text { April }\end{array}$} & \multirow{3}{*}{\begin{tabular}{|c|}
2010 \\
cattle \\
May
\end{tabular}} & \multirow{3}{*}{$\begin{array}{c}\text { cattle } \\
\text { Feb-Mar }\end{array}$} & \multicolumn{2}{|c|}{2011} & \multicolumn{2}{|c|}{2009} & \multicolumn{3}{|c|}{2010} & \multicolumn{2}{|c|}{$2011^{* * *}$} \\
\hline & & & & \multicolumn{2}{|c|}{$\begin{array}{l}\text { Cattle + small } \\
\text { ruminant }\end{array}$} & cattl & & \multicolumn{3}{|c|}{ cattle } & \multicolumn{2}{|c|}{ cattle $\begin{array}{c}\text { Cattle + smal } \\
\text { ruminant }\end{array}$} \\
\hline & & & & \multicolumn{2}{|c|}{ February } & April & May & \multicolumn{2}{|c|}{ February } & March & \multirow{2}{*}{\multicolumn{2}{|c|}{$\begin{array}{c}\text { February } \\
\left(22^{\text {th }} \text { to } 26^{\text {th }}\right)\end{array}$}} \\
\hline Farmers & & & & & & & & $\left(2^{\text {nd }}\right.$ to $\left.6^{\text {th }}\right)$ & $\left(20^{\text {th }}\right.$ to $\left.24^{\text {th }}\right)$ & $\left(20^{\text {th }}\right.$ to $\left.24^{\text {th }}\right)$ & & \\
\hline Household A & 0.83 & 1.82 & 4.09 & 1.25 & 1.34 & $521.9^{* * *}$ & 285.4 & 221.1 & 181.9 & 312.0 & 596.9 & 555.1 \\
\hline Household B & 1.37 & 1.37 & - & 6.44 & 8.37 & 314.9 & 379.1 & - & - & 0.0 & 115.6 & 88.9 \\
\hline Household C & 0.61 & 1.66 & 1.44 & - & - & 703.2 & 312.6 & 626.1 & 515.3 & 883.8 & & \\
\hline Household D & 3.51 & 3.51 & 2.14 & - & - & 123.1 & 148.1 & 423.3 & 348.4 & 597.5 & & \\
\hline Household E & $-^{* * * *}$ & - & 9.54 & - & - & - & - & 94.7 & 78.0 & 133.7 & & \\
\hline Household F & - & - & - & 4.15 & 4.27 & - & - & - & - & - & 179.4 & 174.2 \\
\hline Household G & - & - & - & 4.03 & 4.43 & - & - & - & - & - & 184.4 & 168.1 \\
\hline Household H & - & - & - & 2.69 & 3.08 & - & - & - & - & - & 276.1 & 241.9 \\
\hline Household I & - & - & - & 0.80 & 0.92 & - & - & - & - & - & 929.0 & 807.5 \\
\hline Household J & - & - & - & 11.50 & 12.36 & - & - & - & - & - & 64.7 & 60.2 \\
\hline
\end{tabular}

*: Livestock density was calculated based on the data shown in Table 3 and Table 4, and available grasses for animals were on the data shown in Figure $3^{* *}$ : Average weight of grasses were $10.8,13.0,22.6,18.6$ and $31.9 \mathrm{~g} / 50 \times 50 \mathrm{~cm}^{2}$ in April and May 2009 , February $2^{\text {nd }}$ to $6^{\text {th }}, 20^{\text {th }}$ to $24^{\text {th }}$ and March $13^{\text {th }}$ to $18^{\text {th }} 2010$, respectively. ${ }^{* * *}$ : Average weight of grasses of February $20^{\text {th }}$ to $24^{\text {th }} 2010\left(18.6 \mathrm{~g} / 50 \times 50 \mathrm{~cm}^{2}\right)$ was used for calculation because of lack of data for February 2011. ${ }^{* * * * *}$ : no data. 
Household C in April 2009 (13.7 ha) at the beginning of the rainy season was about three times larger than that in May 2009 (5.0 ha) and January to March 2010 (4.8 ha). Households A and C changed grassland compartments in April and May (Figure 2(a) and Figure 2(b)). On the other hand, Households B and E continued to use the same grassland compartments even in the different seasons in April and May 2009, when the grass conditions were quite different.

Within the study area, farmers can rent land for grazing if required. However, the cost of land rental is high. For example, farmer D paid 1700 Kenyan shillings (Ksh) $(1 \mathrm{Ksh}=0.011$ USD) to rent a small piece of land for one year (0.35 ha) in 2010, which is approximately twice the cattle herder's monthly income of $800 \mathrm{Ksh}$. These high prices force most farmers in this area to use the same lands to raise their animals, although the grass condition or biomass of grasses is limited for grazing.

Nine farmers adopted pattern b) grazing, and one farmer, from Household E, adopted pattern a) grazing (Table 4, Figure 2(c)). The grazing land sizes of pattern b) farmers, Households A, C, and D, in 2010 were 17 48 times larger than that of the pattern a) farmer (Table 4). On the contrary, the livestock density of Household E in 2010 was 2.3 - 6.6 times higher than those of Households A, C, and D (Table 5), meaning that Household E caused severe grazing damage to the land. Thus, the two patterns of grazing affect the land and vegetative conditions in different ways.

Small ruminants were usually taken to the same grassland compartments as cattle. In 2011, the size of the grazing land of Household A was 6.2 hectares, whereas Household $\mathrm{J}$ used 0.4 hectares, approximately 1/15 in size of that used by Household A (Table 4). Likewise, Household G used 1.2 hectares, about 1/5 in size of that used by Household A (Table 4). Head-counts of cattle varied, from 5 to 17 among these 10 households. For the comparison of grazing pressure on lands among these 10 households, livestock density (TLU/ha) was calculated (Table 5). Livestock densities of cattle of Households A and I were 1.25 and $0.80 \mathrm{TLU} / \mathrm{ha}$ in 2011, respectively, which were lower than those of the other households. Household $\mathrm{J}$ had a particularly high density, at 11.50 TLU/ha.

The amount of grass per head of cattle in 2011 was estimated to be $596.9 \mathrm{~kg} / \mathrm{TLU}$ for Household A and 64.7 $\mathrm{kg} / \mathrm{TLU}$ for Household J (Table 5). It was reported that nine African zebu cattle consumed from 6128 to $7228 \mathrm{~g}$ dry grass per head per day with an average of $6712 \mathrm{~g}$ dry grass/head/day [19], and small ruminants consumed $840 \mathrm{~g}$ dry grass/head/day [20]. Thus, it can be calculated that one TLU consumes 8.4 and $9.6 \mathrm{~kg}$ dry grass/head/day (9.0 kg in averaged) for small ruminant and cattle, respectively. Therefore, $596.9 \mathrm{~kg} / \mathrm{TLU}$ are available for 61.7 days in the case of Household A. However, it is available for less than one week (6.6 days) in the case of Household J. In the case of Household B, livestock can graze in the grassland compartment for 9.9 days. Even the other farmers, Households G and H, their livestock could not survive for one month (18.7, 26.8 days, respectively) in their lands.

According to the 57 years of rainfall data measured at the Kenya Agricultural Research Institute (KARI) in Kibos, in this region rain often stops for more than two weeks, once or twice in a year. Furthermore, every few years, rain may stop for a whole one month (personal communication). The repeating periods of heavy rain and dry spells are a common characteristic of the rainfall pattern in many tropical regions. The heavy rain and dry spell is likely to be a major factor causing soil erosion [15]. If rain stops, grass will no longer continue to grow. Under such conditions, livestock farmers, like Household J, could easily suffer a grass shortage.

\section{Conclusions: Overgrazing as a Possible Cause of Soil Erosion}

The average livestock density of seven farmers in February 2011 was 4.41 TLU/ha (Table 5). On the other hand, the average density was obtained from the total number of livestock (861 TLU), and the total available land size (617.9 ha) for grazing (levels $2+3+4$ ) was 1.39 TLU/ha (Table 2 and Table 3). The former livestock density was obtained by measuring the actual land sizes used by farmers, whereas the latter was estimated by analyzing the satellite image. Accordingly, actual size of the grasslands used by livestock was calculated to be $0.23 \mathrm{ha} /$ TLU. However, the available grasslands estimated using the satellite image was $0.72 \mathrm{ha} / \mathrm{TLU}$. Thus, it is clear that the grasslands used by farmers are limited compared with the area of estimated available land for grazing identified by analyzing the satellite image.

Because of a lot of rain (1546.5 mm/year, Figure 1), the biomass of grasses in this study area is expected to be higher than that of the arid-zone. However, it was found to be very small throughout different locations, seasons, and years in this study. Thus, high livestock density and/or small grassland area available for each lives- 
tock might cause reduced biomass of grasses covering these lands.

In addition, based on the growth-consumption rate model developed for the agro pastoral system of southeastern Kenya with the annual rainfall $1200 \mathrm{~mm}$ in the highlands, at higher stocking rates (above $7 \mathrm{TLU} / \mathrm{ha}$ ) pasture growth rate initially lags behind consumption [21]. At least three farmers out of seven farmers kept their livestock at the higher stocking rate (Table 5). In addition, we observed stunted growth of grasses during dry spells that resulted in the deaths of some cattle (Figure 1). Even under grass shortage, livestock tended to eat all the grasses. In particular, sheep often eat grass roots, causing the ground become bare [22]. Shinjo (2003) defined overgrazing as follows: "no continuous re-growth of grasses due to high grazing pressure [9]." We concluded that overgrazing occurred in the study area even for small area and contributed to the soil erosion. Therefore, to prevent soil erosion, the vegetation on grazing lands should be improved by applying effective countermeasures reducing the number of livestock or increasing the area available for grazing.

\section{References}

[1] Cohen, M.J., Brown, M.T. and Shepherd, K.D. (2006) Estimating the Environmental Costs of Soil Erosion at Multiple Scales in Kenya Using Energy Synthesis. Agriculture, Ecosystems \& Environment, 14, 249-269. http://dx.doi.org/10.1016/j.agee.2005.10.021

[2] Barbier, E.B. (2000) The Economic Linkages between Rural Poverty and Land Degradation: Some Evidence from Africa. Agriculture, Ecosystems \& Environment, 82, 355-370. http://dx.doi.org/10.1016/S0167-8809(00)00237-1

[3] Oldemen, L.R. (2000) Impact of Soil Degradation: A Global Scenario. International Soil Reference and Information Center (ISRIC) Working Paper, 10. http://isric.org/isric/webdocs/docs/ISRIC_Report_2000_01.pdf

[4] Hoshino, M., Katsurada, Y., Yamamoto, K., Yoshida, H., Kadohira, M., Sugitani, K., Nyangaga, J.M., Akech, N.O., Mathu, E.M., Ngecu, W.M., Kionyamario, J.I. and Kang'ethe, E.K. (2004) Gully Erosion in Western Kenya. The Journal of the Geological Society of Japan, 110, 3-4. http://dx.doi.org/10.5575/geosoc.110.2.III IV

[5] ICRAF (2006) Improved Land Management in the Lake Victoria Basin: Final Report on the Trans Victoria Project. World Agroforestry Centre, Working Paper. http://www.worldagroforestry.org/downloads/publications/PDFs/OP14439.PDF

[6] Sigunga, D.O., Hoshino, M., Onyango, J.C., Asanuma, S. and Kimura, M. (2011) Pedological Perspective of Gully Erosions Site within Kendu Escarpment-Sondu Miriu Region, West Kenya. African Journal of Environmental Science and Technology, 5, 1050-1059. http://dx.doi.org/10.5897/AJEST10.274

[7] Ong'or, D.O. (2005) Community Participation in Integrated Water Resource Management: The Case of the Lake Victoria Basin. http://www.uni-siegen.de/zew/publikationen/volume0305/on gor.pdf

[8] Muriuki, J., Kuria, A., Mango, J., Ajeho, L., Jamnadass, R. and Mowo, J. (2010) Western Kenya Integrated Ecosystem Management Project (WKIEMP) Reported on Pilot Rehabilitation Activities for Degraded Lands in Western Kenya. World Agroforestry Center Working Paper, 1-21.

[9] Shinjo, H. (2003) Overgrazing. Japan Society for Tropical Agriculture, Ed., Encyclopedia of Tropical Agriculture, In: Japan Society for Tropical Agriculture. Yokendo Press, Tokyo, 90. (In Japanese)

[10] Shipton, P. (2007) The Nature of Entrustment: Intimacy, Exchange, and the Sacred in Africa. Yale University Press, New Haven \& London.

[11] Kristjan, P., Krishna, A., Radeny, M. and Nindo, W. (2004) Pathway Out of Poverty in Western Kenya and the Role of Livestock. Pro-Poor Livestock Policy Initiative (PPLPI) Working Paper. http://www.fao.org/ag/againfo/programmes/en/pplpi/docarc/wp14.pdf

[12] Nyasimi, M., Butler, L.M., Burras, L., Iiahiane, H., Schultz, R. and Flora, J. (2007) Differentiating Livelihood Strategies among the Luo and Kipsigis People in Western Kenya. Journal of Ecology Anthropology, 11, 24-57. http://dx.doi.org/10.5038/2162-4593.11.1.3

[13] Kefa, V.O.R. (2005) Integrated Solar Energy Systems for Rural Electrification in Kenya. Renewable Energy, 30, 2342. http://dx.doi.org/10.1016/j.renene.2004.04.011

[14] Umemura, K., Wanaka, T. and Ueno, T. (2009) Technical Note: Estimation of Feed Intake while Grazing Using a Wireless System Requiring No Halter. Journal of Dairy Science, 92, 1-5. http://dx.doi.org/10.3168/jds.2008-1073

[15] Urushihara, K. (2005) Land Degradation by Sheep Transhumance in the South Carpathian Mountain. Bulletin of the Faculty of Letters, Hosei University, 52, 33-46.

[16] Wint, W. and Bourn, D. (1994) Livestock and Land-Use Surveys in Sub-Saharan Africa. An Oxfam Working Paper. Oxfam Print Unit, Oxford.

[17] Scoones, I. (1992) Land Degradation and Livestock Production in Zimbabwe’s Communal Area. Land Degradation \& 
Development, 1, 99-113. http://dx.doi.org/10.1002/ldr.3400030204

[18] Gufu, O., Vetaas, R.O. and Stenseth, N.C. (2001) Relationships between Biomass and Plant Species Richness in AridZone Grazing Lands. Journal of Applied Ecology, 38, 836-845. http://dx.doi.org/10.1046/j.1365-2664.2001.00638.x

[19] Karue, C.N., Evans, J.L. and Tillman, A.D. (1973) Voluntary Intake of Dry Matter by African Zebu Cattle: Quality of Feed and the Reference Base. Journal of Animal Science, 36, 1181-1185.

[20] Osuga, I.M., Wambui, C.C., Abdulrazak, S.A., Ichinohe, T. and Fujihara, T. (2008) Evaluation of Nutritive Value and Palatability by Goats and Sheep of Selected Browse Foliages from Semiarid Area of Kenya. Animal Science Journal, 79, 582-589. http://dx.doi.org/10.1111/j.1740-0929.2008.00567.x

[21] Nyangito, M.M., Musimba, N.K.R. and Nyariki, D.M. (2008) Range Use and Dynamics in the Agropastoral System of Southeastern Kenya. African Journal of Environmental Science and Technology, 2, 222-230.

[22] Buchanan, H., Laycock, W.A. and Price, D.A. (1972) Botanical and Nutritive Content of the Summer Diet of Sheep on a Tall Forb Range in Southwestern Montana. Journal of Animal Science, 35, 423-430. 